\title{
PENGARUH PENERAPAN MODEL PEMBELAJARAN KOOPERATIF TIPE FORMULATE SHARE LISTEN CREATE TERHADAP PEMAHAMAN KONSEP MATEMATIS SISWA
}

\author{
Usmadi $^{1}$, Sarah Ramdantini ${ }^{2}$, Ergusni ${ }^{3}$ \\ Universitas Muhammadiyah Sumatera Barat ${ }^{1,2,3}$ \\ usmadidttumanggung@gmail.com ${ }^{1}$
}

\begin{abstract}
ABSTRAK
Pemahaman konsep matematis siswa SMP Negeri 5 Padangpanjang belum berkembang secara optimal. Salah satu penyebabnya, guru belum melibatkan siswa secara aktif dalam proses pembelajaran. Untuk mengaktifkan siswa dalam proses pembelajaran dan meningkatkan kemampuan pemahaman konsep matematis siswa salah satunya dengan menerapkan model pembelajaran kooperatif tipe formulate-share-listen-create (FSLC). Tujuan penelitian ini adalah untuk mengungkapkan ada tidaknya pengaruh model pembelajaran kooperatif tipe formulate-share-listen-create terhadap kemampuan pemahaman konsep matematis siswa. Jenis penelitian ini adalah penelitian kuasi eksperimen, dengan one grup pretest-posttest design. Sampel ditarik berdasarkan teknik random sampling, sampel yang terpilih yaitu siswa kelas VII.3 SMPN 5 Padangpanjang dengan jumlah sampel sebanyak 29 orang. Penelitian dilaksanakan pada semester genap tahun pelajaran 2019/2020. Data dikumpulkan melalui tes dan kemudian dianalisis dengan menggunakan uji $\mathrm{t}$ sampel berpasangan. Simpulan hasil analisis data bahwa setiap indikator kemampuan pemahaman konsep matematis siswa meningkat secara signifikan. Melalui uji t pada taraf kepercayaan 95\% diperoleh kesimpulan terdapat pengaruh penerapan model pembelajaran kooperatif tipe FSLC terhadap kemampuan pemahaman konsep siswa.
\end{abstract}

Kata kunci : pembelajaran kooperatif, FSLC, pemahaman konsep

\begin{abstract}
SMP Negeri 5 Padangpanjang students' understanding of mathematical concepts has not developed optimally. One reason for this is that teachers have not actively engaged students in the learning process. One method for engaging students in the learning process and improving students' understanding of mathematical concepts is to use the formulate-share-listen-create (FSLC) cooperative learning model.The aim of this study was to determine whether or not the formulate-share-listen-create cooperative learning model has an effect on students' mathematical concept understanding ability. This is a quasiexperimental study with a one-group pretest-posttest design. The sample was drawn using a random sampling technique, with class VII.3 students from SMPN 5 Padangpanjang making up the total sample of 29 people.The study was conducted during the even semester of the 2019/2020 school year. Tests were used to collect data, which was then analyzed using paired sample t-tests. According to the data analysis, each indicator of students' ability to understand mathematical concepts improves significantly. The application of the FSLC type cooperative learning model had an effect on students' ability to understand concepts, according to the t-test at the 95 percent confidence level.
\end{abstract}

Keywords : cooperative learning, FLSC, concept understanding 


\section{PENDAHULUAN}

Paradigma lama dalam proses pembelajaran matematika adalah guru memberikan pengetahuan secara pasif. Dalam konteks pendidikan, banyak para guru di lapangan mengangap bahwa jika mereka sudah mempunyai pengetahuan dan keahlian dalam suatu bidang matematika, ia pasti akan dapat mengajar, ia tidak perlu mengetahui proses belajar-mengajar dan model pembelajaran untuk menyampaikan ilmu kepada siswa. Sehingga banyak guru matematika menganggap paradigma lama ini sebagai satu-satunya alternatif. Para guru mengajar dengan strategi ceramah dan mengharapkan para siswa duduk, diam, dengar, catat dan hafal (Lie, 2010).

Padahal proses pembelajaran matematika yang diharapkan adalah untuk mengembangkan pengetahuan, keterampilan dan sikap yang lebih baik pada saat siswa berinteraksi dengan lingkungannya. Pembelajaran matematika pada hakikatnya adalah usaha sadar dari seorang guru untuk membelajarkan siswanya (mengarahkan interaksi siswa dengan sumber belajar lainnya) dalam rangka mencapai tujuan yang diharapkan (Trianto, 2012). Guru hendaknya mampu menciptakan pembelajaran yang efektif. Pembelajaran yang efektif akan memberikan pembelajaran yang bermakna dan untuk meningkatkan kemampuan pemahaman konsep matematika siswa. Setelah siswa memahami konsep matematika dengan baik, maka diharapkan mereka juga dapat mengomunikasikan ide atau gagasan matematika dengan baik.

Berdasarkan kenyataan yang ada di lapangan bahwa proses pembelajaran matematika seperti paradigma lama tersebut, masih mendominasi proses pembelajaran di sebagian besar jenjang pendidikan. Akibatnya masih rendahnya hasil belajar matematika siswa, bahkan banyak nilai siswa yang tidak memenuhi Kriteria Ketuntasan Minimal (KKM), serta siswa mengalami kesulitan dalam kemampuan matematis (Prayitno, dkk, 2012:34). Kejadian tersebut juga dialami siswa di SMPN 5 Kota Padangpanjang. Guna mengatasi masalah tersebut dapat dilakukan dengan cara meningkatkan keikutsertaan siswa secara aktif dalam kegiatan pembelajaran. Sebagaimana dikemukan oleh Kemp (Wena, 2016) bahwa perlu adanya kegiatan belajar-mengajar sebagai pendorong siswa untuk aktif berpartisipasi dalam proses pembelajaran. Pembelajaran yang sesuai dengan kondisi tersebut adalah pembelajaran kooperatif.

Pembelajaran kooperatif adalah suatu sistem yang di dalamnya terdapat elemen-elemen yang saling terkait. Nurhadi dan Senduk (Wena, 2016; Lie, 2010) menyatakan bahwa ada beberapa unsur yang dapat diterapkan dalam pembelajaran kooperatif, yaitu: (a) saling ketergantungan positif (positive interdependence); (b) interaksi tatap muka (face to face interaction); (c) akuntabilitas individual (individual accountability); dan (d) keterampilan untuk menjalin hubungan pribadi atau keterampilan sosial yang sengaja diajarkan (use of collarative and social skill).

Berdasarkan hasil penelitian menunjukkan bahwa strategi formulate-sharelisten-create (FSLC) melalui pembelajaran kooperatif ternyata memberikan kesempatan kepada siswa untuk aktif dalam membangun dan memahami materi pelajaran, melalui proses berpikir secara individual maupun bekerjasama dalam kelompok, siswa tidak hanya memikirkan jawaban secara individual tetapi juga memformulasikan dan menuliskan berbagai kemungkinan jawaban dari permasalahan yang diberikan (Emay, 2011; Favero, 2011).

Langkah-langkah model pembelajaran kooperatif tipe FSLC adalah sebagai berikut: (a) Formulate: siswa diberi tugas untuk mempelajari bahan ajar dan menyelesaikan pertanyaan yang ada di LKS; (b) Share: setiap siswa berpasangan 
untuk saling mengajukan pertanyaan yang ada di LKS; (c) Listen: setiap pasangan saling mendengarkan gagasan dan mencatatnya; (d) Create: siswa diberikan kesempatan untuk membuat jawaban baru yang dihasilkan dari kumpulan ide-ide terbaik kelompoknya dan juga kelompok lain; (e) Guru mengevaluasi dan refleksi (Johnson dan Smith dalam Susilawati, 2012).

Penerapan model pembelajaran kooperatif tipe FSLC ini, diharapkan bisa membuat pemahaman konsep matematis siswa akan menjadi lebih baik sehingga kemampuan pemahaman konsep matematis siswa pun dapat meningkat. Indikator yang menunjukkan pemahaman konsep matematis adalah menyatakan ulang sebuah konsep; mengklasifikasikan objek menurut sifat-sifat tertentu sesuai dengan konsepnya; memberikan contoh dan bukan contoh dari suatu konsep; menyajikan konsep dalam berbagai bentuk representasi matematis; mengembangkan syarat perlu dan syarat cukup dari suatu konsep; mengaplikasikan konsep dan algoritma pada pemecahan masalah (Shadiq, 2009:13; Sanjaya, 2009).

\section{METODE}

Jenis penelitian ini adalah kuasi eksperimen. Penelitian kuasi eksperimen ini bertujuan untuk mengetahui ada tidaknya suatu akibat yang ditimbulkan terhadap suatu objek yang diberikan perlakuan tertentu. Rancangan yang digunakan one group pretest-posttest design. Rancangan penelitian dapat dilihat pada Tabel 1.

Tabel 1. Rancangan penelitian one group pretest-posttest design

\begin{tabular}{cccc}
\hline Kelas & Pretest & Treatment & Posttest \\
\hline Eksperimen & $\mathrm{X}_{1}$ & $\mathrm{~T}$ & $\mathrm{X}_{2}$ \\
\hline
\end{tabular}

Suryabrata (2011)

Keterangan :

$\mathrm{T}$ : Pembelajaran kooperatif tipe Formulate Share Listen Create (FSLC)

$\mathrm{X}_{1}:$ Pretest

$\mathrm{X}_{2}:$ Posttest

Populasi pada penelitian ini adalah seluruh siswa kelas VII SMPN 5 Padangpanjang yang terdaftar pada semester genap tahun pelajaran 2019/2020 yang terdiri dari 5 kelas. Pengambilan sampel dengan menggunakan Random Sampling. Sampel yang terpilih adalah kelas VII.3 sebagai kelas yang diberikan perlakuan dengan jumlah siswanya 29 orang.

Variabel dalam penelitian ini adalah kemampuan pemahaman konsep matematis siswa pada pretest dan posttest. Sumber data primer diperoleh melalui tes, sedangkan data sekunder yakni data tentang jumlah siswa yang menjadi populasi dan sampel, serta nilai ulangan harian pokok bahasan bentuk aljabar siswa kelas VII SMPN 5 Padangpanjang.

Prosedur penelitian; tahap persiapan, tahap pelaksanaan, dan tahap akhir. Instrumen tes disusun berdasarkan indikator kemampuan pemahaman konsep matematis siswa. Pada teknik analisis data, dilakukan terlebih dahulu uji normalitas, sehingga sebaran data pada kelas yang diberikan perlakuan berdistribusi normal. Kemudian dilakukan uji homogenitas variansi yang bertujuan untuk melihat apakah data mempunyai variansi homogen atau tidak. Uji hipotesis menggunakan uji t-test untuk data berpasangan pada tingkat kepercayaan $95 \%$. 


\section{HASIL DAN PEMBAHASAN}

Berdasarkan hasil tes kemampuan pemahaman konsep matematis siswa diperoleh nilai rata-rata $(\bar{x})$, nilai tertinggi $\left(x_{\text {maks }}\right)$, nilai terendah $\left(x_{\min }\right)$, persentase ketuntasan dari sampel. Data perhitungan tersebut dapat dilihat pada Tabel 2.

Tabel 2. Data kemampuan komunikasi matematis kelompok sampel

\begin{tabular}{llcll}
\hline Soal & $\mathrm{N}$ & $(\bar{x})$ & $x_{\text {maks }}$ & $x_{\min }$ \\
\hline Pretest & 29 & 38,14 & 69 & 0 \\
\hline Posttest & 29 & 78,21 & 100 & 59 \\
\hline
\end{tabular}

Berdasarkan Tabel 2 dapat diketahui bahwa nilai tertinggi pretest adalah 69 dan nilai tertinggi posttest adalah 100. Nilai terendah pretest 0 dan nilai terendah posttest 59 . Siswa yang tuntas dengan nilai $\geq 72$ sesuai dengan KKM 72 adalah sebanyak 26 orang. Rata-rata nilai pretest adalah 38,14 dan rata-rata nilai posttest adalah 78,21. Peningkatan rata-rata nilai pretest ke posttest adalah 40,07. Dengan demikian dapat disimpulkan bahwa nilai rata-rata kemampuan pemahaman konsep matematis siswa pada soal posttest lebih tinggi daripada soal pretest. Hal ini menunjukkan bahwa kemampuan pemahaman konsep matematis siswa lebih baik setelah penerapan model pembelajaran kooperatif tipe FSLC.

Selanjutnya dilihat kategori kemampuan pemahaman konsep matematis siswa secara perindikator sebagai berikut:

1) Menyatakan ulang sebuah konsep

Berdasarkan analisis yang dilakukan pada lembar jawaban pretest dan posttest siswa, dideskripsikan hasil perkembangan kemampuan menyatakan ulang sebuah konsep seperti pada Tabel 3.

Tabel 3. Jumlah nilai menyatakan ulang sebuah konsep

\begin{tabular}{|c|c|c|c|}
\hline No & Nomor soal & Pretest & Posttest \\
\hline 1 & 1 & 53 & 105 \\
\hline 2 & 2 & 55 & 77 \\
\hline 3 & 3 & 37 & 80 \\
\hline 4 & 4 & 35 & 114 \\
\hline & Jumlah & 180 & 376 \\
\hline
\end{tabular}

Berdasarkan Tabel 3, kemampuan siswa dalam menyatakan ulang sebuah konsep mengalami peningkatan. Nampak bahwa pada soal nomor 1 sampai 4 jumlah nilai dalam menyatakan ulang sebuah konsep matematis pada pretest mengalami peningkatan pada posttest. Hal ini membuktikan bahwa kemampuan siswa dalam menyatakan ulang sebuah konsep meningkat setelah diterapkan pembelajaran Kooperatif Tipe FSLC dalam pembelajaran matematika.

Pada proses pemahaman konsep, siswa dituntut untuk mampu menyatakan ulang sebuah konsep tersebut sampai mendapatkan jawaban yang benar dengan apa yang ditanyakan dalam soal. Hasil pekerjaan salah seorang siswa pada pretest dan posttest dapat dilihat pada Gambar 1 dan Gambar 2. 


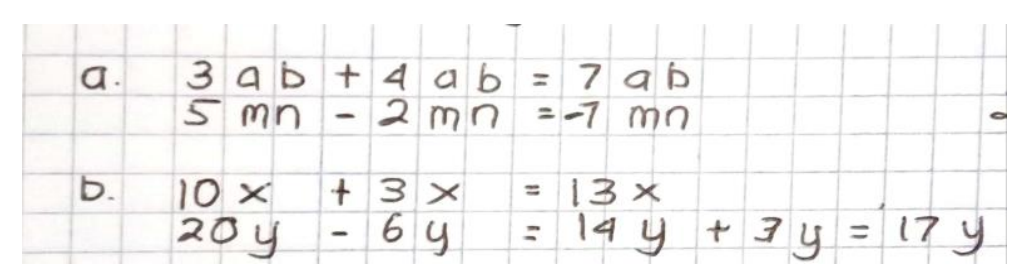

Gambar 1. Hasil kemampuan pemahaman konsep matematis indikator 1 pada pretest

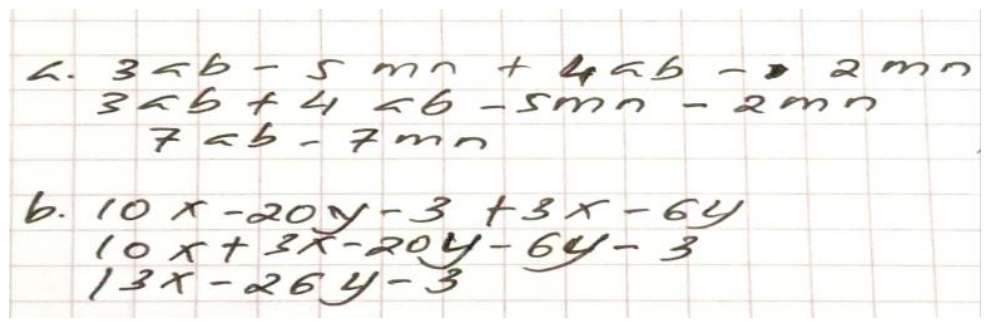

Gambar 2. Hasil kemampuan pemahaman konsep matematis indikator 1 pada posttest

Pada lembar jawaban pretest tidak terlihat jawaban siswa yang memenuhi indikator tersebut. Skor yang diperoleh siswa pada pretest adalah 1, sedangkan pada lembar jawaban posttest siswa sudah memperlihatkan kemampuannya dalam menyatakan ulang sebuah konsep dari soal dengan benar, lengkap, dan sistematis maka skor yang diperoleh siswa tersebut adalah 4. Dalam penyelesaian permasalahan yang diberikan siswa dilatih untuk dapat menyelesaikan masalah dari soal dengan benar, lengkap dan sistematis. Hal ini sangat membantu untuk memicu pemikiran siswa dalam mengerjakan suatu persoalan dan dapat terlihat dari meningkatnya kemampuan siswa pada posttest dalam menyatakan ulang sebuah konsep.

2) Kemampuan mengklasifikasikan objek menurut sifat-sifat tertentu sesuai dengan konsepnya

Berdasarkan hasil analisis yang dilakukan pada lembar jawaban pretest dan posttest siswa, dideskripsikan hasil perkembangan kemampuan pemahaman konsep matematis siswa dalam mengklasifikasikan objek menurut sifat-sifat tertentu sesuai dengan konsepnya. Hasil perkembangan tersebut terlihat pada Tabel 4.

Tabel 4. Jumlah nilai mengklasifikasikan objek menurut sifat-sifat tertentu sesuai dengan konsepnya

\begin{tabular}{cccc}
\hline No & Nomor soal & Pretest & Posttest \\
\hline 1 & 1 & 50 & 105 \\
\hline 2 & 2 & 63 & 77 \\
\hline 3 & 3 & 37 & 75 \\
\hline 4 & 4 & 36 & 114 \\
\hline \multicolumn{2}{c}{ Jumlah } & 186 & 371 \\
\hline
\end{tabular}


Berdasarkan Tabel 4, terlihat bahwa kemampuan siswa dalam mengklasifikasikan objek menurut sifat-sifat tertentu sesuai dengan konsepnya mengalami peningkatan. Hal ini membuktikan bahwa kemampuan siswa dalam mengklasifikasikan objek menurut sifat-sifat tertentu meningkat setelah diterapkan pembelajaran Kooperatif Tipe FSLC. Aspek kemampuan pemahaman konsep yang terkandung dalam indikator ini adalah menyajikan situasi matematika ke dalam berbagai cara serta mengetahui perbedaan. Pada proses pemahaman konsep matematis dari suatu persoalan matematika, siswa dituntut untuk mampu mengklasifikasikan objek menurut sifat-sifat tertentu; seperti pada penjumlahan, pengurangan, perkalian, dan pembagian.

Pada Gambar 3 dan Gambar 4 menunjukkan hasil pekerjaan salah seorang siswa dalam menyajikan situasi matematika ke dalam berbagai cara serta mengetahui perbedaan tata cara menyelesaikan permasalahan pada pretest dan posttest.

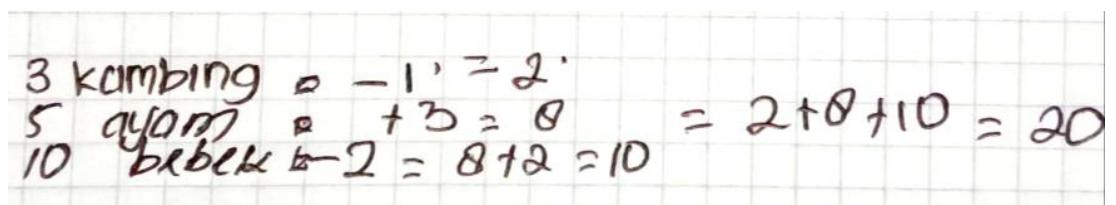

Gambar 3. Hasil kemampuan pemahaman konsep matematis indikator 2 pada pretest

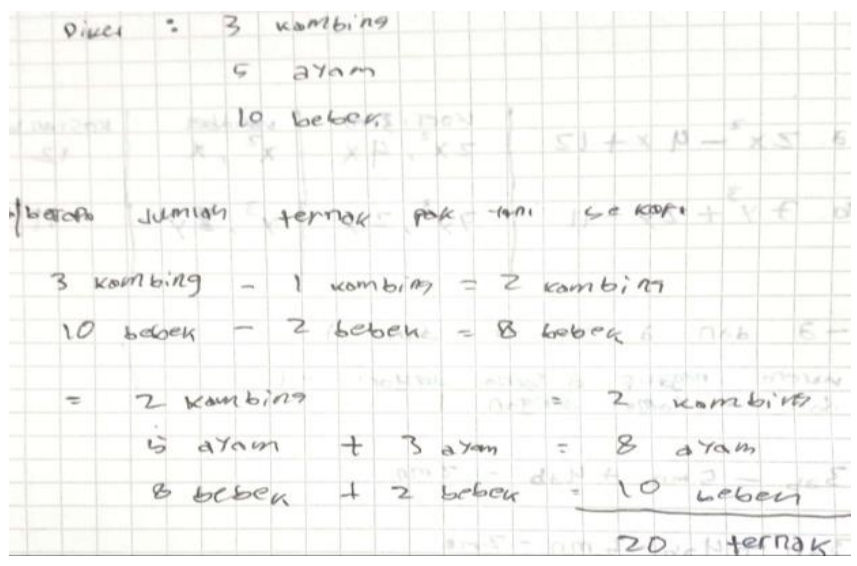

Gambar 4. Hasil kemampuan pemahaman konsep matematis indikator 2 pada posttest

Pada lembar jawaban pretest hampir tidak terlihat jawaban siswa yang memenuhi indikator tersebut. Skor yang diperoleh siswa pada pretest adalah 1, sedangkan pada lembar jawaban posttest siswa sudah memperlihatkan kemampuan dalam menyajikan situasi matematika ke dalam berbagai cara serta mengetahui perbedaan dari penyelesaian matematika secara benar maka skor yang diperoleh siswa tersebut adalah 4. Nampak bahwa kemampuan pemahaman konsep matematika pada pretest lebih rendah daripada posttest. Penyebab hal ini terjadi karena para siswa hanya mementingkan hasil akhir tanpa mengoreksi terlebih dahulu jawaban yang diperoleh sehingga siswa tidak menyimpulkan solusi dari pemecahan masalah matematika tersebut dengan benar. 
Dalam pengerjaan permasalahan yang diberikan pada LKS, siswa dilatih untuk dapat menyajikan situasi matematika ke dalam berbagai cara serta mengetahui perbedaan dari jawaban yang diperoleh dengan benar dan tepat. Hal ini terlihat dari meningkatnya kemampuan siswa pada posttest dalam hal menyajikan situasi matematika ke dalam berbagai cara serta mengetahui perbedaan dari penyelesaian matematika secara benar.

3) Kemampuan mengembangkan syarat perlu atau syarat cukup dari suatu konsep

Berdasarkan hasil analisis yang dilakukan pada lembar jawaban pretest dan posttest siswa, dideskripsikan hasil perkembangan kemampuan pemahaman konsep matematis siswa dalam mengembangkan syarat perlu atau syarat cukup dari suatu konsep sebagaimana pada Tabel 5.

Tabel 5. Jumlah nilai kemampuan mengembangkan syarat perlu atau syarat cukup dari suatu konsep matematika

\begin{tabular}{cccc}
\hline No & Nomor soal & Pretest & Posttest \\
\hline 1 & 1 & 49 & 105 \\
\hline 2 & 2 & 50 & 68 \\
\hline 3 & 3 & 34 & 73 \\
\hline 4 & 4 & 32 & 114 \\
\hline & Jumlah & 165 & 360 \\
\hline
\end{tabular}

Berdasarkan Tabel 5, terlihat pada soal nomor 1 sampai 4 terdapat peningkatan nilai dari pretest kepada nilai posttest. Hal ini membuktikan bahwa kemampuan siswa dalam mengembangkan syarat perlu atau syarat cukup dari suatu konsep meningkat setelah diterapkan pembelajaran Kooperatif Tipe FSLC.

Pada proses pemahaman konsep matematis suatu persoalan matematika, siswa dituntut untuk mampu mengembangkan syarat perlu dan syarat cukup dari suatu konsep atau membuatkan jawaban yang benar dengan apa yang ditanyakan dalam soal. Gambar 5 dan Gambar 6 menunjukkan hasil pekerjaan salah seorang siswa dalam menyatakan syarat perlu dan syarat cukup dari suatu konsep pada pretest dan posttest.

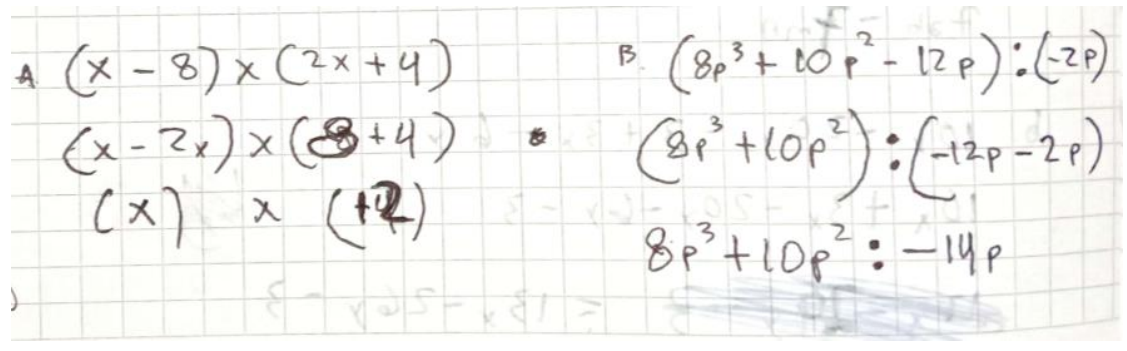

Gambar 5. Hasil kemampuan pemahaman konsep matematis indikator 3 pada pretest 


$$
\begin{aligned}
< & (x+8)(2 x+4) \\
& 2 x^{2}+4 x+16 x+32 \\
& 2 x^{2}+20 x+32 \\
\text { b. } & \left(\frac{8 p^{3}}{-2 p}\right)+\left(-\frac{10 p^{2}}{2 p}\right)-\left(\frac{12 p}{-2 p}\right) \\
= & -4 p^{2}-5 p-6
\end{aligned}
$$

Gambar 6. Hasil kemampuan pemahaman konsep matematis indikator 3 pada posttest

Pada lembar jawaban pretest, belum terlihat jawaban siswa yang memenuhi indikator tersebut. Skor yang diperoleh siswa pada pretest adalah 1 , sedangkan pada lembar jawaban posttest siswa sudah memperlihatkan kemampuan siswa dalam mengembangkan syarat perlu atau syarat cukup dari suatu konsep dari penyelesaian matematika secara benar, maka skor yang diperoleh siswa tersebut mencapai 4. Kemampuan siswa dalam mengembangkan syarat perlu atau syarat cukup dari suatu konsep pada soal pretest masih rendah dibandingkan dengan nilai posttest. Penyebab utama kebanyakan siswa kurang mengoreksi jawaban yang sudah dibuat terlebih dahulu, sehingga siswa tidak dapat menyimpulkan solusi dari pemecahan masalah tersebut.

Dalam pengerjaan permasalahan yang diberikan pada LKS, siswa dilatih untuk dapat mengembangkan syarat perlu atau syarat cukup dari suatu konsep dari jawaban yang diperoleh dengan benar dan tepat. Hal ini terlihat dari meningkatnya kemampuan siswa pada posttest dalam mengembangkan syarat perlu atau syarat cukup dari suatu konsep.

4) Kemampuan menggunakan, memanfaatkan, dan memilih prosedur atau operasi tertentu

Berdasarkan hasil analisis yang dilakukan pada lembar jawaban pretest dan posstest siswa, dideskripsikan hasil perkembangan kemampuan pemahaman konsep matematis siswa dalam menggunakan, memanfaatkan, dan memilih prosedur atau operasi tertentu, seperti pada Tabel 6 .

Tabel 6. Jumlah nilai kemampuan dalam menggunakan, memanfaatkan, dan memilih prosedur atau operasi tertentu

\begin{tabular}{cccc}
\hline No & Nomor soal & Pretest & Posttest \\
\hline 1 & 1 & 50 & 103 \\
\hline 2 & 2 & 59 & 66 \\
\hline 3 & 3 & 34 & 70 \\
\hline 4 & 4 & 31 & 114 \\
\hline & Jumlah & 174 & 353 \\
\hline
\end{tabular}

Berdasarkan Tabel 6, terlihat bahwa kemampuan siswa dalam menggunakan, memanfaatkan, dan memilih prosedur atau operasi tertentu mengalami peningkatan. Hal ini membuktikan bahwa kemampuan siswa dalam menggunakan, memanfaatkan, dan memilih prosedur atau operasi tertentu meningkat setelah diterapkan pembelajaran Kooperatif Tipe FSLC. 
Pada proses pemahaman konsep matematis suatu persoalan matematika, siswa dituntut untuk mampu menggunakan, memanfaatkan, dan memilih prosedur atau operasi tertentu tersebut sampai mendapatkan jawaban yang benar dengan apa yang ditanyakan dalam soal. Gambar 7 dan Gambar 8 menunjukkan hasil pekerjaan salah seorang siswa pada pretest dan posttest.

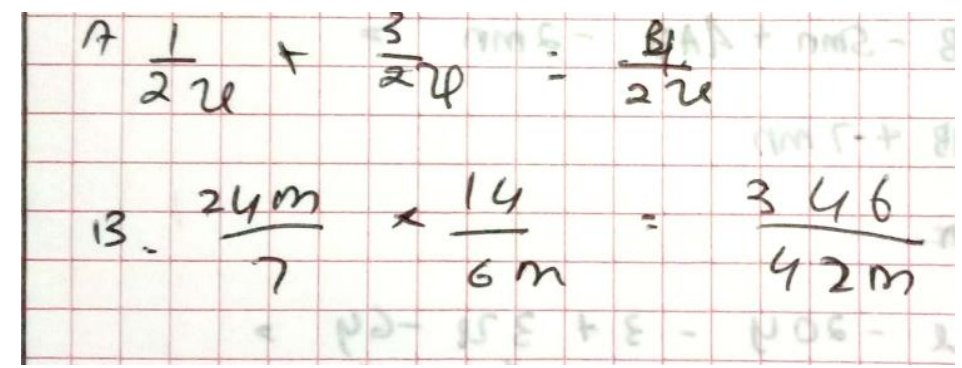

Gambar 7. Hasil kemampuan pemahaman konsep matematis indikator 4 pada pretest

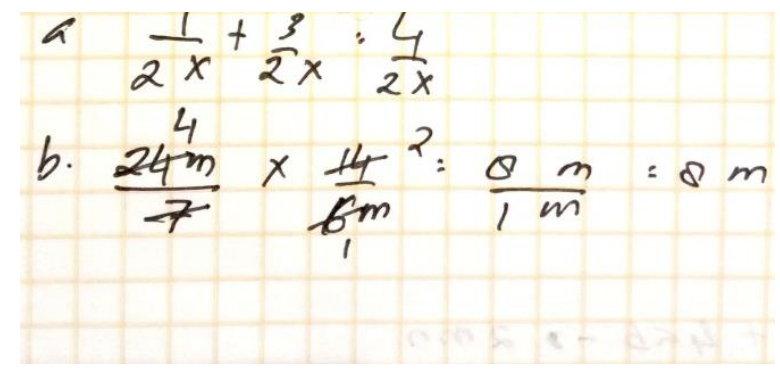

Gambar 8. Hasil kemampuan pemahaman konsep matematis indikator 4 pada posttest

Pada lembar jawaban pretest, jawaban siswa belum memenuhi indikator tersebut. Skor yang diperoleh siswa pada pretest adalah 1, sedangkan pada lembar jawaban posttest siswa sudah memperlihatkan kemampuan dalam menggunakan, memanfaatkan, dan memilih prosedur atau operasi tertentu dari penyelesaian matematika secara benar maka skor yang diperoleh siswa tersebut adalah 4.

Kemampuan siswa dalam menggunakan, memanfaatkan, dan memilih prosedur atau operasi tertentu pada pretest untuk soal lebih rendah dibandingkan pada posttest, hal ini disebabkan oleh hampir seluruh siswa hanya mementingkan hasil akhir tanpa mengoreksi terlebih dahulu jawaban yang diperoleh sehingga siswa tidak menyimpulkan solusi dari pemecahan masalah matematika. Dalam pengerjaan permasalahan yang diberikan pada LKS, siswa dilatih untuk dapat menggunakan, memanfaatkan, dan memilih prosedur atau operasi tertentu dari jawaban yang diperoleh dengan benar dan tepat. Hal ini terlihat dari meningkatnya kemampuan siswa pada nilai posttest menggunakan, memanfaatkan, dan memilih prosedur atau operasi tertentu.

Hipotesis penelitian yang diuji adalah penerapan model pembelajaran kooperatif Tipe FSLC berpengaruh secara signifikan terhadap kemampuan pemahaman konsep matematis siswa dalam pembelajaran matematika. Berdasarkan analisis data diperoleh bahwa sebaran data berdistribusi normal dan bervariansi homogen, maka untuk menguji hipotesis digunakan uji t-test untuk data berpasangan. 
Berdasarkan hasil analisis data pada taraf kepercayaan 95\% $(\alpha=0,05)$ diperoleh $t_{\text {hitung }}=8,78>t_{(0,05 ; 28)}=1,701$ yang berarti $H_{0}$ ditolak atau hipotesis $H_{a}$ diterima. Dengan demikian dapat disimpulkan bahwa penerapan model pembelajaran kooperatif Tipe FSLC berpengaruhi secara signifikan terhadap kemampuan pemahaman konsep matematis siswa dalam pembelajaran matematika. Dalam hal ini penerapan model pembelajaran kooperatif Tipe FSLC dalam pembelajaran matematika dapat meningkatkan hasil belajar terkait dengan penguasaan konsep matematis siswa di kelas VII SMPN 5 Kota Padangpanjang.

Secara umum indikator yang digunakan untuk kemampuan pemahaman konsep matematis siswa dalam capaian hasil belajar meningkat secara signifikan dari pretest ke posttest. Peningkatan kemampuan pemahaman konsep matematis dengan penerapan model pembelajaran kooperatif tipe FSLC, penyebabnya diduga adalah guru dalam proses pembelajaran mencoba meningkatkan persepsi siswa atau menciptakan lingkungan pembelajaran yang kondusif dengan menampilkan teknik manajemen pengelolaan kelas yang kondusif, mempertahankan perhatian dalam pembelajaran. Hal ini sejalan dengan pendapat Keller, Callahan, dkk (Wena, 2016:37) bahwa untuk membangkitkan persepsi siswa dapat dilakukan dengan menghindari gangguan yang dapat mengurangi perhatian atau penataan lingkungan pembelajaran yang kondusif sangat penting. Begitu pula, untuk mempertahankan perhatian siswa dalam proses pembelajaran, guru dapat menggunakan hal-hal yang baru, mengherankan, tidak pantas atau peristiwa-peristiwa pembelajaran yang tidak menentu. Dengan meningkatkan persepsi siswa maka hasil belajar akan tinggi.

Begitu pula kegiatan yang dilakukan guru untuk memotivasi siswa adalah mengaitkan pembelajaran dengan kebutuhan siswa dengan cara menumbuhkan keakraban dan kebiasaan yang baik, menyajikan isi pembelajaran yang berorientasi pada tujuan, menggunakan strategi pembelajaran yang sesuai yakni strategi FSLC. Seperti yang dinyatakan Sardiman (2006:21) apabila siswa memiliki motivasi belajar yang baik maka proses pembelajaran akan mencapai keberhasilan. Sebagai pendidik dan motivator, guru harus memotivasi siswa untuk belajar demi tercapainya keberhasilan belajar.

Kemudian penyebab lainnya terjadinya peningkatan pemahaman konsep matematis siswa karena siswa diberikan kesempatan untuk menemukan sendiri pemahaman mereka tentang ide dan konsep matematika melalui penyelesaian masalah yang diberikan. Proses untuk siswa memahami konsep matematika ini dilatih dengan siswa bekerja secara berkelompok dalam menyelesaikan permasalahan dan menemukan ulang konsep yang ada pada LKS yang diberikan. Mengerjakan LKS secara berkelompok sangat membantu siswa memahami prinsipprinsip matematika. Hal ini sejalan dengan hasil penelitian Astuti (2016) yang menyatakan bahwa pembelajaran dengan menggunakan LKS dengan metode diskusi kelompok efektif untuk mempengaruhi hasil belajar siswa.

Hasil penerapan model pembelajaran kooperatif tipe FSLC dalam penelitian ini telah memberikan gambaran bahwa terdapat peningkatan kemampuan pemahaman konsep matematis siswa. Simpulan ini sejalan dengan penelitian lain tentang proses pembelajaran matematika dengan menerapkan model kooperatif tipe FSLC yang memberikan hasil bahwa penerapan model kooperatif tipe FSLC secara signifikan telah dapat meningkatkan hasil belajar, kemampuan komunikasi matematis, penalaran matematis, dan pemahaman konsep matematis siswa (Prayitno dkk, 2012; Budiarweni dkk. 2014; Juariah dan Sari, 2014; Oktavianti dkk, 2020). 


\section{SIMPULAN DAN SARAN}

Berdasarkan hasil analisis data dan pembahasan dapat disimpulkan bahwa penerapan model pembelajaran kooperatif tipe Formulate Share Listen Create (FSLC) berpengaruh secara signifikan terhadap kemampuan pemahaman konsep matematis siswa. Peningkatan secara signifikan ini ditinjau dari nilai pretest dan posttest yang diperoleh oleh siswa.

Berdasarkan hasil penelitian ini disarankan kepada para guru matematika untuk menerapkan model pembelajaran kooperatif tipe FSLC dalam pembelajaran di sekolah, sedangkan untuk peneliti selanjutnya diharapkan bisa diperluas pokok bahasan yang diujicobakan dan indikator lain pada pemahaman konsep matematis.

\section{DAFTAR PUSTAKA}

Astuti, B.I.D. 2016. Efektivitas Penggunaan Lembar Kerja Siswa Pada Pembelajaran Matematika Pokok Bahasan Bilangan Bulat Ditinjau dari Hasil Belajar dan Pemahaman Siswa Kelas VII Compassion SMP Joannes Bosco Yogyakarta. Skripsi tidak diterbitkan. Yogyakarta: Universitas Sanata Dharma. [Online]. Tersedia: https://repository.usd.ac.id/3806/2/111414089_full.pdf

Budiarweni, M.A.R., Sugiarta, I.M., dan Gita, I.N. 2014. Pengaruh Penerapan Model Pembelajaran Kooperatif Tipe Formulate-Share-Listen-Create (FSLC) Terhadap Kemampuan Penalaran Matematis. Jurnal Pendidikan Matematika Undiksha, Vol. 2(1). [Online]. https://ejournal.undiksha.ac.id/index.php/JJPM/article/view/3990

Emay, A. 2011. Peningkatan Kemampuan Pemahaman dan Komunikasi Matematis Siswa Sekolah Menengah Pertama dengan Menggunakan Pembelajaran Kooperatif Tipe Formulate Share Listen Create (FSLC). Tesis tidak diterbitkan. Bandung: Universitas Pendidikan Indonesia. [Online]. Tersedia: http://repository.upi.edu/9484/.

Favero, T.G. 2011. Active Review Sessions Can Advance Student Learning. Advances In Physiology Education, Vol. 35(3) : 247-248.

Juariah dan Sari, R. 2014. Penerapan Model Pembelajaran Kooperatif dengan Formulate Share Listen Create (FSLC) Untuk Meningkatkan Kemampuan Penalaran Matematis Siswa. Kreano, Jurnal Matematika Kreatif-Inovatif, Vol $5(2): 143-149$.

Lie, A. 2010. Cooperative Learning. Jakarta: Grasindo.

Oktavianti, N.W., Astawa, I.W.P., dan Sariyasa. 2020. Pengaruh Model Pembelajaran Kooperatif Tipe Formulate Share Listen Create (FSLC) Terhadap Kemampuan Komunikasi Matematis Siswa Kelas X SMA Negeri 1 Payangan. Wahana Matematika dan Sains: Jurnal Matematika, Sains, dan Pembelajarannya, Vol. 14(1) : 148-155.

Prayitno, A.T., Rochmad, dan Mulyono. 2012. Pembelajaran Kooperatif Tipe Formulate Share Listen And Create Bernuansa Konstruktivisme Untuk Meningkatkan Kemampuan Komunikasi Matematis. Lembaran Ilmu Kependidikan: Journal of Education Research, Vol. 41(1) : 33-38. [Online]. Tersedia https://journal.unnes.ac.id/nju/index.php/LIK/article/view/2227.

Sanjaya, W. 2009. Strategi Pembelajaran Berorientasi Standar Proses Pendidikan. Jakarta: Prenada. 
Sardiman, A.M. 2006. Integrasi dan Motivasi Belajar. Jakarta: PT Raja Grafindo Persada.

Shadiq, F. 2009. Kemahiran Matematika. Yogyakarta: Depdiknas.

Suryabrata, S. 2011. Metodologi Penelitian. Jakarta: PT. Raja Grafindo Persada.

Susilawati, W. 2012. Belajar dan Pembelajaran Matematika. Bandung: CV. Insan Mandiri.

Trianto. 2012. Mendesain Model Pembelajaran Inovatif-Progresif. Jakarta: Kencana Prenada Media Group.

Wena, M. 2016. Strategi Pembelajaran Inovatif Kontemporer (Suatu Tinjauan Konseptual Operasional). Jakarta: Bumi Aksara. 